\title{
The Arrival Of A New GAAP: International Financial Reporting Standards
}

Brian B. Stanko, Loyola University Chicago, USA

Thomas L. Zeller, Loyola University Chicago, USA

\begin{abstract}
This article examines the International Accounting Standards Board's efforts to create greater comparability and uniformity in global financial reporting. Prefacing this will be an examination of 1) the reasons for past and present inter-country reporting differences and 2) the changes that have affected the governing structure of the international financial reporting environment. Most importantly, however, this article explores the areas that will be most impacted when companies move to a uniform group of international accounting standards. An understanding of the accounting regulatory process and the changes underway is important for all businesses professionals, including those in large and small businesses alike, and understanding how to read and interpret the language of business is important to competing in today's smaller world.
\end{abstract}

Keywords: International Financial Reporting Standards (IFRSs), International Accounting Standards Committee (IASC), Generally Accepted Accounting Principles (GAAP)

\section{INTRODUCTION}

C $\mathrm{t}$ has been said that accounting is the "language of business," and though not all users need to create the language, all users should be able to "read" the language. For decades, however, it has been difficult to read and understand company performance when financial information originated from different global locations. Many of these companies effectively prepared financial statements under different accounting rules and regulations. As a result, the different rules created different values or measures for the same economic event.

The lack of financial statement comparability influenced business decisions in many ways. Often, the lack of comparability and ability to understand performance would change 1) a company's decision to acquire an overseas operation, 2) an analyst's recommendation or rating when reviewing the creditworthiness of a foreign entity, 3) an investor's decisions concerning global investment opportunities, or 4) a domestic organization's decision to use an overseas supplier. ${ }^{1}$ Thus, the lack of financial statement comparability would result in lost opportunities for a business. Today a business professional that works in a global economy must be able to efficiently and effectively evaluate the profitability, liquidity, and financial position of its business partners and competitors to thrive and grow.

This article examines the International Accounting Standards Board's efforts to create greater comparability and uniformity in global financial reporting. Prefacing this will be an examination of 1) the reasons for past and present inter-country reporting differences and 2) the changes that have affected the governing structure of the international financial reporting environment. Most importantly, however, this article explores the areas that will be most impacted when companies move to a uniform group of international accounting standards. An understanding of the accounting regulatory process and the changes underway is important for all businesses professionals, including those in large and small businesses alike. And understanding how to read and interpret the language of business is important to competing in today's smaller world.

\footnotetext{
${ }^{1}$ Nancy Anderson, "The Globalization GAAP," Management Accounting, August 1993, 52-55.
} 


\section{INTER-COUNTRY REPORTING DIFFERENCES}

There are many market variables that have influenced a country's accounting and financial reporting policy. One such variable has been a country's level of industrial development. Countries that have experienced significant industrial growth throughout the past century have seen far greater advances in the sophistication of their accounting systems than those who have not achieved the same success. Quality accounting information is demanded by credit providers and investors (the ultimate information user) to support such rapid expansion.

Another variable that has influenced a country's accounting framework has been its income tax structure. In the United States, for example, Congress develops the tax laws and requires business entities to determine taxable income in accordance with these rules. Congress, however, has had minimal influence on the determination of book or financial reported income and the subsequent external reporting to shareholders and other users of financial information. Other countries' external reporting, however, has been heavily influenced by their taxing authorities. Germany, Japan, and Sweden, for example, have historically required their corporations to report substantially the same book and taxable income. While this eliminates some problems, many believe that this approach compromises the conceptual foundation of financial reporting.

A country's political and economic ties have also influenced its accounting system. Frequently, countries that have traded heavily with each other and raised capital within each other's territories required corporate entities to use the same accounting rules and conventions. And countries that provide limited vehicles for capital formation have tended to be influenced by the demands of their capital providers. For example, German, Japanese, and Swiss corporations have relied heavily on their country's banking structure for capital infusion. Thus, their respective accounting and reporting practices have been heavily influenced by their lending institutions. ${ }^{2}$

\section{THE CHANGING GOVERNING STRUCTURE OF THE INTERNATIONAL FINANCIAL REPORTING ENVIRONMENT}

International accounting standards originally developed under the direction of the International Accounting Standards Committee (IASC), organized in 1973. The Committee was an independent private sector body whose objective was to provide uniformity in the accounting principles used by businesses and other organizations for financial reporting around the world. Its formation was via an agreement among professional accountancy bodies of Australia, Canada, France, Germany, Japan, Mexico, the Netherlands, the United Kingdom, Ireland, and the United States. Over time IASC membership expanded.

Accounting standards were set by a part-time, volunteer IASC Board that had 13 country members and up to 3 additional organizational members. Each member was generally represented by two "representatives" and one "technical advisor". The individuals came from a wide range of backgrounds - accounting practice, business (particularly multinational businesses), financial analysis, accounting education, and national accounting standardsetting. ${ }^{3}$

The committee's progress during its existence included the completion of a "core" set of 39 accounting rules, known as International Accounting Standards (IASs) with a focus on establishing industry-specific accounting rules. At that juncture, the committee was awaiting acceptance of the standards by the U. S. Securities and Exchange Commission (SEC) and the like commissions of other countries. A positive decision would allow companies to list their stock on foreign exchanges (known as cross-border listings). The organization that was responsible for authorizing and allowing cross-border listing decisions was the International Organization of Securities Commissions (IOSCO). ${ }^{4}$ This IOSCO includes U.S. SEC representation. This organization had approximately 150 securities regulatory agencies from around the world as participating members. IOSCO's recommendation in 1993 compelled the IASC to develop a "core" set of accounting rules which, as mentioned above, was completed in early

\footnotetext{
${ }^{2}$ Gerhard G. Mueller, Helen Gernon, and Gary Meek, Accounting: An International Perspective (New York: Irwin/McGraw Hill, 1997), 20.

${ }^{3}$ http://www.iasplus.com/restruct/restruct.htm

$4 \underline{\mathrm{http}: / / \text { en.wikipedia.org/wiki/International_Organization_of_Securities_Commissions }}$
} 
1999. At the time, The Wall Street Journal suggested that the new rules not only would simplify bookkeeping for international companies, but could also increase cross-border capital flow and open the door to bigger international mergers. 5

As early as 1997, however, the IASC recognized that in order to create convergence among the world's standard setters, it needed to reexamine its strategy and structure. As a result of this review, the IASC Board approved a new International Accounting Standards Board Constitution, which took effect in July 2000. The IASC standards-setting body was renamed the International Accounting Standards Board (IASB) and it would operate under a new International Accounting Standards Committee Foundation (IASCF). The current trustees of the IASCF are shown below in Exhibit A. ${ }^{6}$

\section{Exhibit A: Trustees of the IASC Foundation}

\section{Trustees of the IFRS Foundation}

Trustee

Gerrit Zalm Chairman of the IASCF Trustees (effective 1 January 2008)

Former Deputy Prime Minister (2003-2007) and Finance Minister (19942002, 2003-2007) of the Netherlands

Philip A Laskawy

Vice Chairman of the IASCF Trustees

Retired Chairman, Ernst \& Young International

\section{Marvin Cheung}

Retired Chairman of KPMG Hong Kong

Bertrand Collomb

Chairman, Association Francaise des Entreprises Privees

Samuel DiPiazza

CEO, PricewaterhouseCoopers

Oscar Fanjul

Immediate Past Chairman and President, Japanese Institute of Certified Japan

Retired chairman and chief executive officer, NASD (the private sector

\section{From}

The Netherlands

United States

Hong Kong SAR, People's Republic of 31 December 2008 China

France

31 December 2009

United States

31 December 2008

United States

31 December 2008

Germany

31 December 2010

31 December 2010
Vice Chairman, Omega Capital, and former Chairman Founder and CEO, Spain

Repsol, SA

\section{Tsuguoki (Aki) Fujinuma}

Public Accountants, Japan

\section{Robert Glauber} regulator of the US securities market), and former Under Secretary of the Treasury for Finance, United States

\section{Max Dietrich Kley}

Member of the Supervisory Board, BASF AG

${ }_{6}^{5}$ Elizabeth McDonald, "U.S. Accounting Board Faults Global Rules," The Wall Street Journal, 18 October $1999,1$.

${ }^{6}$ http://www.iasplus.com/restruct/whatis.htm\#iasc 
Alicja Kornasiewicz

Member of the Board of CA IB Corporate Finance Gmbh Vienna, and CEO Poland

31 December 2010

and Chairman, CA IB Group in Poland

Liu Zhongli

President, Chinese Institute of Certified Public Accountants; former Minister, Ministry of Finance

\section{Jeffrey Lucy}

Former Chairman of the Australian Securities and Investments Commission and current Chairman of the Australian Financial Reporting Council

\section{Pedro Malan}

Former Finance Minister and former president of the Central Bank of Brazil, and currently chairman of the board of Unibanco

\section{Sir Bryan Nicholson}

Former Chairman, Financial Reporting Council

\section{T. V. Mohandas Pai}

Chairman of the Board, Infosys BPO Limited

\section{Jeff van Rooyen}

Chief Executive, Uranus Investment Holdings; former Vice Chairman Executive Committee, International Organization of Securities Commissions (IOSCO); former CEO, South African Financial Services Board

\section{David L Shedlarz}

Former Vice Chairman of Pfizer Inc

David Sidwell

Former Executive Vice President and Chief Financial Officer, Morgan Stanley

\section{Luigi Spaventa}

Former chairman of the Commissione nazionale per le societa e la borsa (Consob) and former Minister of the Budget, Italy

\section{Paul Tellier}

Former President and CEO of Bombardier and CN, former Clerk of the Privy Council and Secretary of the Cabinet

\section{Junichi Ujiie}

Chairman, Nomura Holdings Inc

Antonio Vegezzi

Former President and Director of Capital International SA

People's Republic of 31 December 2008
China

Australia

31 December 2010

Brazil

31 December 2010

United Kingdom

31 December 2008

India

31 December 2008

South Africa

31 December 2009

United States

United States

Italy

Canada

Japan

Switzerland
31 December 2009

31 December 2008

31 December 2009

31 December 2009

31 December 2008

31 December 2010

Since 2001, the standard-setting responsibility of the IASCF has been conducted by the 14-members of the IASB. An International Financial Reporting Interpretations Committee (IFRIC) of the IASB develops and solicits comment on interpretive guidance for applying standards promulgated by the IASB. The IASB must approve the interpretations developed by the IFRIC. The objectives of the Board are: 
1. to develop, in the public interest, a single set of high quality, understandable and enforceable global accounting standards that require high quality, transparent and comparable information in financial statements and other financial reporting to help participants in the world's capital markets and other users make economic decisions;

2. $\quad$ to promote the use and rigorous application of those standards; and

3. in fulfilling the objectives associated with (a) and (b), to take account of, as appropriate, the special needs of small and medium-sized entities and emerging economies; and,

4. to bring about convergence of national accounting standards and International Accounting Standards and International Financial Reporting Standards to high quality solutions. ${ }^{7}$

Similar to the process followed by the United States Financial Accounting Standards Board in establishing Generally Accepted Accounting Principles (GAAP), the IASB's due process of standard setting generally includes the following steps:

1. identify and review the issues associated with the topic and to consider the application of the Framework to the issues;

2. study national accounting requirements and practice and exchange views about the issues with national standard-setters;

3. consult the Standards Advisory Council about the advisability of adding the topic to the IASB's agenda;*

4. form an advisory group (generally called a 'working group') to advise the IASB and its staff on the project;

5. publish for public comment a discussion document;

6. publish for public comment an exposure draft approved by vote of at least nine IASB members, including any dissenting opinions held by IASB members (in exposure drafts, dissenting opinions are referred to as 'alternative views');**

7. publish within an exposure draft a basis for conclusions;

8. consider all comments received within the comment period on discussion documents and exposure drafts; *

9. consider the desirability of holding a public hearing and the desirability of conducting field tests and, if considered desirable, holding such hearings and conducting such tests;

10. approve a standard by at least votes of at least nine IASB members and include in the published standard any dissenting opinions; $*$ and

11. publish within a standard a basis for conclusions, explaining, among other things, the steps in the IASB's due process and how the IASB dealt with public comments on the exposure draft. ${ }^{8}$

* Steps minimally required by the IASB

As a result of the aforementioned "due process", the IASB has issued eight International Financial Reporting Standards (IFRSs) since its organization and has revised a number of the previously promulgated International Accounting Standards (IASs) by its predecessor, the IASC.

With the financial reporting world moving toward a uniform, global set of International Financial Reporting Standards, the process of establishing an authoritative standard involves U.S. GAAP adjusting toward IFRSs and IFRSs adjusting toward U.S. GAAP. As a result, the set of global accounting standards that U.S. companies eventually adopt presently does not exist. ${ }^{9}$

The U.S. Securities and Exchange Commission (SEC) is the driving force in the U.S. for a uniform set of IFRSs. Presently, more than 12,000 companies in approximately 100 countries follow the entire set of IFRSs. ${ }^{10}$ In 2007, the U.S. SEC authorized IFRS financial statements for foreign filers without requiring reconciliation to U.S. GAAP. This means that companies no longer have to convert financial statements that were in accordance with

\footnotetext{
${ }^{7}$ http://www.iasplus.com/restruct/whatis.htm

${ }^{8}$ http://www.iasplus.com/restruct/restruct.htm\#board

9 Bruce Pounder (2008). Myths and Facts About Convergence, Strategic Finance. 90(3), 59-60.

${ }^{10}$ International Financial Reporting Standards (IFRS): An AICPA Backgrounder, (2008) Journal of Accountancy 206(3), A1A11.
} 
non-US GAAP to US GAAP financials. Many U.S. companies have the option to follow IFRSs beginning in 2009.

In November of 2008 the U.S. SEC announced a proposed timeframe for moving towards IFRSs for U.S. companies: ${ }^{11}$ The proposal commits the SEC staff to monitor four of seven identified milestones through 2011 . The first four milestones are: ${ }^{12}$

- Improved IFRS. The IASB would have to continue to improve IFRS through its independent standard setting and its convergence work with the FASB.

- Accountability and funding of the IASC Foundation

- Improvement in the ability to use interactive data for IFRS reporting in an XBRL format. (XBRL is an abbreviation of "Extensible Business Reporting Language.)

- Progress in education and training (Investors, management, auditors, educators, actuaries, valuation professional, for example.) to prepare, audit, read and understand IFRS.

"If the SEC believes these four are achieved by 2011, it would also consider whether IFRS, as issued by the IASB, is a globally accepted set of accounting standards and whether it is consistently applied when determining whether to mandate its use by U.S. public companies. ",13 The SEC votes on this proposal in February 2009.

The remaining three milestones address action plans for the SEC based on the developments of the above action plans: ${ }^{14}$ These are:

- $\quad$ Allow early, yet limited use of IFRS where it would enhance financial-reporting comparability. U.S. public companies may file IFRS financial statements beginning in December 15. 2009, if they meet two specific conditions. A) The company industry group uses IFRS as the reporting standard. B) The company is among the 20 largest in the industry group.

- Anticipate rulemaking in 2011. Assuming satisfactory achievement of the first four milestones, the SEC will determine whether it is in the interest of the U.S. investors to proceed with rules that would require all U.S. public companies to use IFRS.

- $\quad$ Phases-in, mandatory use of IFRS over a three-year period. Large companies begin December 15, 2014, smaller reporting companies, would begin IFRS filings for years ending on or after December 15, 2016.

While considering the above, understand that U.S. GAAP is driven by detailed accounting rules while IFRS is driven by broad accounting principles. This means the GAAP authoritative literature is designed to provide specific guidance in the practice of accounting. The IFRS authoritative literature provides general guidance to the practicing professional yet providing meaningful financial information to the user. This means the deployment of IFRS standards calls upon more judgment in its application than does GAAP. Research has not addressed empirically the advantages and disadvantages of this change to accounting practice authoritative guidelines.

\section{ADOPTING THE NEW INTERNATIONAL GAAP: IMPACT ON U.S. FINANCIAL REPORTING ${ }^{15}$}

Mentioned earlier in this paper was the notion that the monetary effect of different financial reporting rules can amount to millions of dollars of differences between company financial statements. And while a uniform set of financial reporting standards would resolve this problem, the initial adoption of international standards by U. S.

\footnotetext{
${ }^{11}$ Paul H. Munter, Holger Erchinger, and Kristopher A. McKinley, Defining Issues: SEC Proposed Roadmap for Mandatory IFRS Filings by U.S. Public Companies. November 2008. This is a publication of KPMG's Department of Professional Practice - Audit 212-909-5600. https://clients.amr.kpmg.com/NR/rdonlyres/1F8D246C-C355-4F07-9DEBA5CE15EE299F/0/DefiningIssues0847.pdf

${ }_{12} \mathrm{http}: / / \mathrm{sec} . \mathrm{gov} / \mathrm{rules} / \mathrm{proposed} / 2008 / 33-8982 . \mathrm{pdf}$

13 Ibid, KPMG

${ }^{14} \mathrm{http}: / / \mathrm{sec} . \mathrm{gov} / \mathrm{rules} /$ proposed/2008/33-8982.pdf

15 While many areas of accounting will be affected by a change to IFRS, the authors have decided to discuss a selected few for the sake of brevity and ease of understanding by a business professional. Complicated details have been omitted from the discussion and certain standards have been ignored due to the standard's technical nature and evolving changes in moving to one global standard.
} 
companies would have a significant impact on current financial reporting. Following are some examples of changes to present financial reporting practices. The authors believe these changes will withstand the test of time as IFRS further develop.

\section{FINANCIAL STATEMENT PRESENTATION}

One initial substantive difference between U.S. GAAP and IFRS involves financial statement presentation. The balance sheet, income statement and statement of cash flow are each affected. ${ }^{16}$ A brief summary of these differences follows:

\section{Income Statement}

The primary difference in the income statement rests in reporting expenses. U.S. GAAP requires expenses to be reported by function, while IFRS allows expenses to be reported by function or nature. Examples of reporting by nature or are shown in Exhibits B and C, respectively.

Exhibit B: Analysis by Nature of Expense [IAS1R.91]

\begin{tabular}{|l|r|r|r|}
\hline Revenue & & & \\
\hline & & & \\
\hline Other income & & \\
\hline $\begin{array}{l}\text { Changes in inventories of finished goods and work } \\
\text { in progress }\end{array}$ & $X$ & & \\
\hline Raw materials and consumables used & $X$ & \\
\hline Employee benefit costs & $X$ & & \\
\hline Depreciation and amortisation expense & $X$ & \\
\hline Other expenses & & \\
\hline & & & $(\mathrm{X})$ \\
\hline Total expenses & & \\
\hline Profit & & \\
\hline
\end{tabular}

Exhibit C: Analysis by Function of Expense [IAS1R.92]

\begin{tabular}{|l|r|}
\hline Revenue & $X$ \\
\hline Cost of sales & $(\mathrm{X})$ \\
\hline & \\
\hline Gross profit & $\mathrm{X}$ \\
\hline Other income & $\mathrm{X}$ \\
\hline Distribution costs & $(\mathrm{X})$ \\
\hline Administrative expenses & $(\mathrm{X})$ \\
\hline Other expenses & $(\mathrm{X})$ \\
\hline & \\
\hline Profit & $\mathrm{X}$ \\
\hline
\end{tabular}

\footnotetext{
${ }^{16}$ Pages 1-5 of the financial statement illustrations found at: http://www.pwc.com/gx/eng/about/svcs/corporatereporting/ICFS08.pdf provide excellent examples of IFRS based financial statements.
} 


\section{Balance Sheet}

The primary difference between a U.S. GAAP balance sheet and an IFRS balance sheet is in the order of presentation. U.S. GAAP financial statements follow an order of liquidity reporting structure, with a careful delineation between current and non-current assets and liabilities. This means the most liquid assets are reported first in the current asset section of a balance sheet and liabilities requiring the most immediate cash in the coming year are reported in the current liabilities sections of the balance sheet. IFRS do not specify the balance sheet format or structure. The guidelines simply say the balance sheet must show the entity's assets, liabilities and equities. A company is not required to list assets or liabilities in order of liquidity but is required to specify each section of assets and liabilities as current and noncurrent.

\section{Statement of Cash Flows}

U.S. GAAP and IFRS follow an identical reporting structure for the Statement of Cash Flows. There is a difference between U.S. GAAP and IFRS in the classification of interest and dividend cash flows, which is summarized in Exhibit D.

Exhibit D: U.S. GAAP and IFRS Cash Flow Classifications

\begin{tabular}{|c|c|c|}
\hline Cash flow & U.S. GAAP & IFRS \\
\hline Interest Received & Operating & Operating or investing ${ }^{17}$ \\
\hline Interest Paid & Operating & Operating or financing \\
\hline Dividends Received & Operating & Operating or investing \\
\hline Dividends Paid & Financing & Operating or financing \\
\hline
\end{tabular}

\section{INVENTORY}

IAS 2 Inventories serves as the authoritative IFRS. A discussion of inventory differences is important because it is a component of business that often consumes significant company resources. Three major differences exist between IFRS and U.S. GAAP for inventory.

First, IFRS and U.S. GAAP report inventory design expenses differently. Design expenses are included in the cost of inventory for IFRS purposes. Design expenses are not included in the cost of inventory for GAAP reporting purposes.

Second, IFRS and U.S. GAAP measure inventory differently. IAS 2 does not allow the last in, first out (LIFO) method of inventory valuation. This difference may result in a substantial measurement difference for many companies. U.S. GAAP provides for the use of LIFO, first in, first (FIFO) or weighted average (WA) of inventory valuation. When a company that uses LIFO changes to a FIFO or WA inventory valuation, there will likely be significant adjustments to earnings, related ratios and tax consequences. The specific roll out of this change is yet to be specified in the U.S. GAAP or IFRS literature. However, a careful monitoring of this situation is necessary for profit planning and tax management. Failure to monitor this situation could result in a substantial and unplanned tax liability. IFRS also requires the same carrying value of inventory for tax and financial reporting purposes. In addition, IAS 2 specifies all inventories of similar use are subject to the same measurement method.

Last, there is a difference in the accounting for inventory write-downs. U.S. GAAP requires the lower of cost or market approach to reduce inventory value. The word market means the cost to replace the inventory via a purchase or internal production. IFRS IAS 2 states inventories to be measured at the lower of cost or net realizable value. IAS 2 defines net realizable value as - "the estimated selling price in the ordinary course of business less the estimated costs of completion and the estimated costs necessary to make the sale." ${ }^{\prime 8}$ Essentially, the U.S. GAAP

\footnotetext{
${ }^{17}$ Interest received and dividends received should each be classified separately and are normally classified as investing activities [IAS7.31]

${ }^{18}$ http://www.iasplus.com/standard/ias02.htm
} 
market value approach to measurement is externally driven with a view on replacement. The IFRS net realizable value approach to measurement takes a disposal perspective. In addition, U.S. GAAP does not allow for a reversal of the write down. IFRS does allow for a reversal of the write down to its original value, if business conditions warrant such an adjustment.

\section{PROPERTY, PLANT AND EQUIPMENT}

U.S. GAAP and IFRS both initially measure property, plant and equipment at cost. Cost includes all costs incurred in bringing the asset to the place of business and getting it ready for its intended use. Companies are not allowed to include (capitalize) start up costs, general and administrative costs or overhead in the cost of the asset.

A significant difference between U.S. GAAP and IFRS pertains to asset valuation. According to IAS 16 Property, Plant and Equipment ${ }^{19}$, companies can follow the cost model or the revaluation model. The cost model is simply recording an asset at cost and subsequently depreciating the asset over time. The asset's carrying value is therefore "cost less accumulated depreciation." This approach is consistent with U.S. GAAP. The revaluation approach, on the other hand, is quite different than the cost approach. Under the revaluation approach, a company carries its depreciable assets at fair value less any accumulated depreciation. Revaluation increases are subsequently recognized in the balance sheet asset section and equity section. No upward adjustment impacts the income statement. Revaluation decreases impact a company's balance sheet as well as its income statement. This would require a decrease to the assets carrying value and an expense in the income statement. The impact on the income statement, however, can only take place after all upward adjustments to equity have been eliminated as a result of prior upward revaluations. The biggest challenge to asset revaluation is the subjectivity of the measurement. Research has yet to examine the bias of reporting revaluation.

\section{CONTINGENT LIABILITIES}

Contingent liabilities ${ }^{20}$ exist when a company has the responsibility to settle an obligation that is probable and reasonably estimable. As a result, both U.S. GAAP and IFRS require companies to accrue liabilities that will ultimately consume future economic resources. A significant difference between the rules, however, lies in the measurement of the obligation. Under U.S. GAAP, companies are required to estimate a range of cost associated with settling the obligation and use the low end of that range for measurement purposes. IFRS IAS 37 Provisions, Contingent Liabilities and Asset ${ }^{21}$, on the other hand, requires that companies report the mid-point of that range. As a result, IFRS prepared balance sheets will have significantly higher reported contingent liabilities.

\section{LEASES}

U.S. GAAP and IFRS have similar lease accounting rules with regard to classification and measurement. A slight difference exists, however, in the criteria considered when classifying a lease as "operating" or "capital". Under U.S. GAAP, companies are required to capitalize ${ }^{22}$ a lease obligation when at least one of the following four criteria has been satisfied.

1. The lease contract includes a transfer of title clause;

2. The lease contract contains a bargain purchase option;

3. The lease contract term constitutes $75 \%$ or more of the useful life of the leased asset; and

4. The present value of the minimum lease payments is $90 \%$ or more of the fair value of the leased asset.

\footnotetext{
${ }^{19} \mathrm{http}: / /$ www.iasplus.com/standard/ias16.htm

20 An example of a contingent liability is the estimated clean-up cost associated with an environmental disaster created by a specific company.

${ }^{21} \mathrm{http} / / /$ www.iasplus.com/standard/ias37.htm

22 Capitalization occurs when a company (the lessee) records a leased asset and a related lease liability on the balance sheet as a result of signing a lease contract. Capital leases are measured by calculating the present value of the future minimum lease payments. If a lease is classified as an operating lease, a company only reports a periodic lease (rental) expense, thus no asset or liability.
} 
Under IFRS 17 Leases $^{23}$ the same four criteria apply, however, the thresholds of $90 \%$ and $75 \%$ have been eliminated from consideration. The reason for this is that IFRS are principles-based standards while U.S. GAAP standards are rules-based. Many proponents of IFRS dislike the precise thresholds that are often applied under U.S. GAAP reporting and support the use of professional judgment when classifying leases.

\section{PENSIONS}

IAS 19 Employee Benefits ${ }^{24}$ and SFAS 158 Employers' Accounting for Defined Benefit Pension and Other Post Employment Benefit Plans ${ }^{25}$ have many similarities with respect to recognition and measurement. Some differences, however, still remain. The most significant remaining difference when comparing U.S. GAAP to IFRS, is that under U.S. GAAP the pension liability (asset) for a defined benefit plan is measured by comparing the pension plan assets at the balance sheet date with the projected benefit obligation (PBO) at the balance sheet date. If the plan assets are less than the PBO, the company recognizes a pension liability. If the opposite is true then the company recognizes an asset, "prepaid pension expense." This is referred to as the "funding status" of the plan.

Under IFRS, the funding status does not constitute the reported liability (asset) if actuarial gains/losses and unrecognized prior service costs exist. These are the result of changes in mortality tables, discount rates, salary growth rates, or enhancements to benefit formulas with the provision for retroactive benefits. In essence, the reported liability is equal to the PBO minus the plan assets but then reduced (or increased) by actuarial gains (or actuarial losses and prior service cost).

Future amendments to these rules appear to be headed toward no longer deferring the recognition of gains/losses or unrecognized prior service costs. The belief seems to be that these effects should be recognized as expenses in the period in which the adjustment takes place. Therefore, if an actuarial adjustment is made in 2009, then the related gain/loss should affect pension expense and the related pension asset/liability in that year. Likewise, if a company modifies the benefit formula in 2009 , then the resulting adjustment should affect pension expense and the related pension asset/liability in that year, as well.

\section{CONCLUSION}

According to Securities and Exchange Commission Chairman Christopher Cox, "The expanded use of a single, high-quality accounting standard will eventually empower investors to make better-informed investment decisions by giving them information that is more easily comparable." His speech came just a few months after the SEC began accepting IFRS-prepared financial statements from some of its foreign registrants without requiring them to reconcile those filings to U.S. generally accepted accounting principles. ${ }^{26}$ With that being said, is your accounting function ready for IFRS?

The debate about a global standard for financial reporting has changed. For many years the debate focused on if there would eventually be one global set of widely accepted accounting standards. Today the debate is when will a global set of widely accepted accounting standards be accepted and fully embraced. A recent survey by the American Institute of Certified Public Accountants (AICPA) ${ }^{27}$ revealed the following:

"A 55 percent majority of CPAs at firms and companies nationwide now say they are preparing in a variety of ways for adoption of IFRS, an increase of 14 percentage points from 41 percent who were preparing for change according to an AICPA survey in April, 2008. At the same time, the number of respondents who aren't yet preparing for IFRS dropped by an equal amount. Forty-five percent said in the new survey they are not yet preparing for IFRS, al4-percentage point shrinkage from 59 percent in April who had said they weren't preparing for IFRS."

\footnotetext{
${ }^{23} \mathrm{http}: / / \mathrm{www}$. iasplus.com/standard/ias17.htm

24 http://www.iasplus.com/standard/ias19.htm

25 http://www.fasb.org/pdf/fas158.pdf

${ }_{26}$ Johnson, S. "IFRS: NO longer If, But When", CFO.Com, February 8, 2008.

${ }^{27}$ Roberts, W. "U.S. CPAs Show Growing Acceptance of Change from U.S. to International Accounting Standards", AICPA, December 3, 2008.
} 
Those that have already made the change to IFRS offer two pieces of advice. First, changing to IFRS requires institutional change. Full adaptation to IFRS will mean changes to internal controls, IT systems, cash management systems, income taxes, contractual arrangements, and compensation plans. Change throughout the many business processes calls upon the judgment of the accounting and business professional working together. Second, many companies understate the work required and time to comply with IFRS. ${ }^{28}$ The changes in data capture, management, and reporting, take time to be institutionalized into the fabric of the business enterprise, much like U.S. GAAP is today.

\section{AUTHOR INFORMATION}

Professor Brian B. Stanko received a Ph.D. in Accounting from the University of Kentucky. He is currently Department Chair and MSA Program Director at Loyola University Chicago. Professor Stanko's primary research and writing interests concern financial reporting standards and the understanding of corporate annual reports. He is the coauthor of three books and has published articles in The Journal of Accounting and Public Policy, Issues in Accounting Education, Corporate Controller, The Government Accountants Journal, Strategic Finance, Journal of Business Ethics, The CPA Journal, and International Advances in Economic Research. Professor Stanko's teaching responsibilities have included principles, intermediate, and graduate level accounting courses.

Thomas L. Zeller is a Professor of Accounting in the Department of Accounting and Business Law at Loyola University Chicago. He has published numerous articles and books. His research appears in a wide variety of academic and practitioner journals, including Strategic Finance, Journal of Accounting and Public Policy, Business Horizons, Healthcare Financial Management, and Issues in Accounting Education. Routinely he presents to professional groups and businesses on topics addressing financial analysis, activity-based costing and business measurement. He teaches graduate and undergraduate level courses in accounting at Loyola. $\mathrm{He}$ is actively involved as a Center for Corporate Financial Leadership (CCFL) teaching seminars in financial measurement and capital budgeting. He is a member of the American Accounting Association, Illinois CPA Society and American Institute of Certified Public Accountants.

\footnotetext{
${ }^{28}$ Baker, N. “Getting Up to Speed with IFRS”, Internal Auditor [serial online], October 2008; 65(5): 32-37.
} 


\section{NOTES}

